\title{
TIME TO DIAGNOSIS OF CANCER IN STROKE PATIENTS
}

\author{
Zeynep ÖZÖZEN AYAS, Gülgün UNCU \\ University of Health Sciences, Eskişehir City Health Application and Research Center, Department of \\ Internal Medical Sciences, Neurology Clinic, Eskişehir, TURKEY
}

\begin{abstract}
INTRODUCTION: Stroke and cancer are diseases that lead to disability and mortality in society. We aimed to identify the clinical characteristics of patients who had a stroke under a known cancer diagnosis and stroke patients who were found to have cancer at the same time or during the 1-year post-stroke follow-up period. Stroke patients with cancer were compared with non-cancerous stroke patients. (not diagnosed with cancer during a 5-year follow-up)

METHODS: Age, sex, subtype of stroke, conventional risk factors (CRF), localization, cancer types, presence of metastasis, duration between cancer-stroke diagnoses, mortality, and stroke-death periods were analysed.

RESULTS: Fifty-seven stroke patients (35M, 22F) with cancer and 295 stroke patients $(154 \mathrm{~F}, 141 \mathrm{M})$ without cancer were included. Ischemic stroke was most common subtypes in stroke patients with cancer (89.4\%). The presence of CRF and the comorbidity of diabetes mellitus and coronary artery disease in the patients without cancer was determined to be significantly higher compared to with cancer. $(\mathrm{p}=0.000, \mathrm{p}=0.038, \mathrm{p}=0.000)$ Bilateral hemisphere involvement was detected to be significantly higher in the stroke with cancer. $(\mathrm{p}=0.012)$ Forty-two of the stroke patients with cancer were diagnosed with cancer before $(25.9 \pm 32.4$ months $)$, and 15 of them were diagnosed with cancer after the diagnosis of stroke $(5.2 \pm 4.9$ months). Six of 15 patients were diagnosed with the cancer at the same time with the diagnosis of the stroke, while 9 of them were diagnosed with cancer during the post-stroke 1-year follow-up. The rate of females was determined to be significantly higher in the group diagnosed with cancer before having a stroke compared to after having a stroke.( $\mathrm{p}=0.003$ ) $40.4 \%$ of stroke patients with cancer died in $6.7 \pm 12.3$ months.

DISCUSSION AND CONCLUSION: The absence of CRF and bilateral hemisphere involvement should make us think of the coexistence of cancer and stroke. Particular consideration should be given to the potential diagnosis of cancer in the 1year follow-up of patients after having a stroke.
\end{abstract}

Keywords: Stroke, cancer, duration between stroke-cancer, follow-up stroke patients.

\footnotetext{
Address for Correspondence: Zeynep Özözen Ayas, MD. University of Health Sciences, Eskişehir City Health Application and Research Center, Department of Internal Medical Sciences, Neurology Clinic, Eskisehir, Turkey.

Phone: +902226114000 E-posta: zozozen@hotmail.com

Received: $30.03 .2020 \quad$ Accepted: 14.06 .2021

ORCID IDs: Zeynep Özözen Ayas Öztürk 0000-0002-6923-2235, Gülgün Uncu 0000-0002-0063-4869.

Please cite this article as following: Özözen Ayas Z, Uncu G. Time to diagnosis of cancer in stroke patients. Turkish Journal of Cerebrovascular Diseases 2021; 27(2): 160-168. doi: 10.5505/tbdhd.2021.02360
} 


\section{INME HASTALARINDA KANSER TANI ZAMANI}

\section{ÖZ}

GİRIŞ ve AMAÇ: İnme ve kanser hastalıkları toplumda engelliğe ölüm yol açan hastalıklardır. Bilinen bir kanser tanısı altında inme geçiren hastalar ile aynı zamanda veya inme sonrası 1 yıllık takip döneminde kanser tespit edilen inme hastalarının klinik özelliklerini belirlemeyi amaçladık. Kanserli olan inme hastaları, kanserli olmayan inme hastaları (5 yıllık takipte kanser tanısı almayan) ile karşılaştırıldı.

YÖNTEM ve GEREÇLER: Yaş, cinsiyet, inme alt tipi, geleneksel risk faktörleri (GRF), lokalizasyon, kanser tipleri, metastaz varlığı, kanser inme teşhisleri arasındaki süre, mortalite ve inme-ölüm arası süreler değerlendirildi.

BULGULAR: Kanserli inme olan 57 hasta (35E, 22K), kansersiz inme tanısı olan 295 hasta (154K, 141E) alındı. İskemik inme, kanserli inmelerde en sık görülen alt tip idi. (\%89.4) Kansersiz inme grubunda, GRF varlığı ve diabetes mellitus, koroner arter hastalığı komorbiditeleri kanserli inme grubundan anlamlı olarak yüksek saptandı.(p=0.000,p=0.038, $\mathrm{p}=0.000$ ) Kanserli inme olan grupta bilateral hemisfer tutulum oranı kansersiz inmelere göre anlamlı düzeyde yüksek

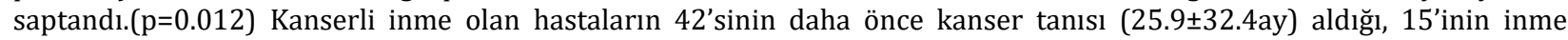
tanısından sonra kanser tanısı (5.2 \pm 4.9 ay) aldığı tespit edildi. Onbeş hastanın 6'sının inme ile aynı zamanda, 9'unun ise inme sonrası izlemde kanser tanısı aldığı kaydedildi. İnme öncesi kanser tanısı alan grupta kadın cinsiyetin inme sonrası kanser tanısı alan gruba göre anlamlı düzeyde yüksek olduğu saptandı.(p=0.003) Kanserli inme hastalarının \%40.4'ünün inmeden sonra $6.7 \pm 12.3$ ayda eksitus oldu.

TARTIŞMA ve SONUÇ: GRF'nin olmaması ve bilateral hemisfer tutulumu bize kanser ve inmenin birlikteliğini düşündürmelidir. Özellikle hastaların inme sonrası 1 yıllık izlemlerinde potansiyel kanser tanısı açısından dikkatli olunmalıdır.

Anahtar Sözcükler: İnme, kanser, inme-kanser arası süre, inme hastalarının takibi.

\section{INTRODUCTION}

Stroke and cancer diagnoses are diseases that cause disability in society and have significant mortality rates. In the comorbidity of cancer, stroke can be detected after cancer diagnosis, as well as before malignancy as the first sign of cancer $(1,2)$. In cancer patients, stroke is the most common central nervous system problem after metastases and chemotherapy-induced neurotoxicity $(1,3)$. In the autopsy study, which was performed by Graus et al., the most common central nervous system complication following metastasis in cancer patients was infarction and hemorrhage, and it was revealed that $14.6 \%$ of cancer patients had evidence of pathological cerebrovascular disease and half of them were symptomatic (4). Besides, the comorbidity of stroke in cancer is considered as a factor that worsens the prognosis (5). Stroke patients with cancer have longer hospital stays and worse clinical outcomes compared to stroke patients without cancer (2).

In the comorbidity of stroke and cancer, patients may be diagnosed with cancer during the investigation of the etiology of stroke. A study reported that $16.6 \%$ of patients who underwent etiological investigations due to acute stroke were diagnosed with cancer (6). More rarely, the presence of cancer may also be detected in the outpatient clinic follow-up after stroke.

An increased risk of stroke is observed among cancer patients compared to the normal population. (7). Stroke in cancer patients can also develop with different mechanisms other than conventional risk factors. One of these factors is the direct tumor effect that results from tumor compression or tumor embolism $(8,9)$. Another important factor is coagulation disorders. The coagulation system is activated, and thrombotic occlusion occurs due to the distribution of microthrombi in small vessels. Moreover, depletion of platelets and coagulation factors increases the risk of hemorrhage (10). Since cancer patients are immunosuppressed, there is an increased risk of sepsis and disseminated intravascular coagulopathy and septic cerebral infarcts, as well as an increased risk of stroke due to mycotic aneurysms (1). Factors arising from therapeutic and diagnostic interventions (vascular trauma and tissue factor release during surgery) in cancer patients might also lead to stroke $(1,11)$. Complications of chemotherapy, radiotherapy, and the above-mentioned interventions can develop during treatment and even years after treatment (12). In most patients, a combination of more than one factor plays a role in thromboembolism.

The purpose of the this study is to present an 
analysis of the association of cancer among stroke patients. Our objectives are to identify clinical (demographic features, subtypes of stroke, presence of conventional risk factors) and radiological features of stroke with cancer patients compared to stroke without cancer patients. Furthermore, we present the comparison of clinical and radiological features, mortality ratio of cancer diagnosis before and after stroke. It was aimed to identify the clinical characteristics of stroke patients who had a stroke under a known cancer diagnosis, which was diagnosed previously, and stroke patients who were found to have cancer at the same time or during the 1-year poststroke follow-up period.

\section{METHODS}

In order to perform the study, ethical approval was obtained from Eskișehir Osmangazi University Noninterventional Clinical Research Ethical Committee (Number: E-25403353-050.9977356, Date: July 14th, 2020). The study was conducted in accordance with the ethical standards of the Declaration of Helsinki.

Three thousand ninety-eight patients who were followed up with the diagnosis of stroke in the neurology clinic, intensive care unit, and outpatient clinic of Eskisehir State Hospital and Eskisehir City Hospital between January 1, 2015 and January 1, 2020, were reviewed in our study. Patients with a previous medical history of cancer who were admitted to the hospital for the etiology of stroke concurrently or in regular outpatient follow-ups for 1 year after stroke were included in the study. The disease diagnosed with history, neurological examination and neuroimaging by neurologist. Subtypes of stroke were determined with CT and/or MRI, or cerebral MR venography. Stroke mimicking conditions (toxic-metabolic disorders, brain tumor, infections, psychological disorders, migraines, seizures, demyelization disorders) were excluded.

Age, sex, stroke subtypes (arterial ischemic stroke and hemorrhagic stroke, cerebral sinus venous thrombosis (CVT)), presence of conventional risk factors for stroke (hypertension (HT), diabetes mellitus (DM), hyperlipidemia (HL), coronary artery disease (CAD), atrial fibrillation (AF), previous stroke history, valvular heart disease, thyroid disorders) were recorded. While the cerebrovascular system circulation and hemisphere involvement of the patients were being analyzed, patients with CVT were excluded from the assessment. Patients with arterial ischemic and hemorrhagic stroke were grouped as anterior, posterior, and anterior-posterior circulation system involvement according to cerebrovascular system involvement, and unilateral or bilateral hemisphere involvement according to hemisphere involvement. The data of stroke patients with the comorbidity of cancer regarding the cancer types, the duration between cancer and stroke diagnoses, the presence of metastasis during stroke, the duration between stroke and death in mortal cases were recorded.

Age, sex, stroke subtypes, presence of risk factors for stroke, cerebrovascular system circulation, and hemisphere involvement were recorded in patients who were followed up with a diagnosis of stroke for 5 years in our clinic but were not diagnosed with cancer before and after. In our retrospective study, clinical characteristics of stroke patients with and without cancer were compared.

There was an alteration in hospital information system of patients medical records. Some medical database are unavailable. So, we can not use etiological classifications as an TOAST.

Statistical Analysis: In the descriptive statistics of the data, mean, standard deviation, median minimum and maximum, frequency, and ratio values were used. The distribution normality of variables was tested with the KolmogorovSmirnov test. The Mann-Whitney U-test was used to analyze quantitative independent data. The Chisquare test was used in the analysis of qualitative independent data and the Fischer test was used when the conditions of the chi-square test were not met. The level of statistical significance was set at $\mathrm{P}<0.05$. The statistical analyzes were performed via the software of SPSS, version 27.0.

\section{RESULTS}

A total of 3098 stroke patients were included in the analyses for 5 years; of these 57 (1.8\%) patients (35 male, 22 female) had stroke and cancer diagnosis, 295 patients (154 female, 141 male) who were followed up with a diagnosis of stroke for 5 years but were not diagnosed with cancer before and after were included in the study. The rest were not included comparison. It was not 
clear whether they had cancer. Because the patients who were followed up in different centers, certain information could not be obtained and could not be clearly stated in our retrospective study. The mean age of patients with cancer and stroke $(n=57)$ was $67.5 \pm 13.8$, and it was $70.3 \pm 13.1$ 70.313.1 for patients in the stroke without cancer $(n=295)$ (Table I). There was no significant difference between the two groups in terms of age and sex (Table I).

Fifty-one (89.4\%) of the patients with stroke and cancer were ischemic, while $5(8.8 \%)$ of them had hemorrhagic stroke, and 1 patient $(1.8 \%)$ had CVT. In the stroke without cancer, it was detected that $243(82.4 \%)$ of the patients were ischemic, while $48(16.3 \%)$ of them were hemorrhagic, and $4(1.3 \%)$ were with CVT. No significant difference was found between the two groups in terms of stroke subtypes (Table I).

While a conventional predisposing risk factor for stroke was detected in the history of 35 patients $(61.4 \%)$ with stroke and cancer, it was detected in $246(83.4 \%)$ patients in the stroke without cancer. The most common risk factors in the group with cancer and stroke were HT, DM, AF, stroke, HL, CAD, thyroid disorders, respectively. $(30,10,5,4,4,1,1)$. The most common risk factors in the stroke without cancer were determined as HT, CAD, DM, AF, stroke, HL, thyroid disorders, and valvular heart diseases, respectively (195, $111,92,42,39,34,12,2)$. The presence of conventional risk factors in the group of stroke without cancer was found to be significantly higher compared to stroke with cancer $(p=0.000)$. Moreover, the presence of DM and CAD in the stroke without cancer was found to be significantly higher compared to stroke with cancer $(p=0.038, p=0.000)$ (Table I).

Based on the cerebrovascular system circulation involvement in arterial ischemic and hemorrhagic stroke with cancer $(n=56), 39$ $(69.6 \%)$ of them had anterior circulation system, and $9(16.1 \%)$ had posterior circulation involvement, while $8(14.3 \%)$ of them had anterior and posterior circulation systems involvement. It was detected that in the stroke without cancer $(n=291), 186(63.9 \%)$ patients had anterior circulation and $76(26.1 \%)$ had an involvement of the posterior circulation system, while 29 (10\%) of them had anterior and posterior circulation system involvement. No significant difference was determined between the two groups, regarding stroke subtypes. When hemisphere involvement was assessed, unilateral involvement was detected in $41(73.2 \%)$ patients of stroke with cancer, and bilateral involvement was detected in 15 (26.8\%) of them. In the stroke without cancer, 253 patients (86.9\%) had unilateral involvement and 38 patients (13.1\%) had bilateral involvement. When the two groups were compared, the rate of bilateral hemisphere involvement in the stroke with cancer was significantly higher compared to the stroke without cancer $(\mathrm{p}=0.012)$ (Table I).

No significant difference was determined between the stroke with and without cancer groups in terms of age, sex, subtypes of stroke, and circulation involvement (Table I).

It was found that $42(73.7 \%)$ (21 male, 21 female) of patients with cancer and stroke were diagnosed with cancer before having a stroke among 57 patients diagnosed with stroke with cancer. Fifteen (14 male, 1 female) (26.3\%) of 57 were diagnosed with cancer after having a stroke (Table II). It was noted that 6 of these 15 patients were diagnosed with cancer concurrently with acute stroke, and 9 of them were diagnosed with cancer during the period of post-stroke follow-up in 1-year (Figure). The rate of females was determined to be significantly higher in the group diagnosed with cancer before having a stroke compared to the group diagnosed with cancer after being diagnosed with stroke $(p=0.003)$. The mean duration between the diagnoses of cancer and stroke in patients diagnosed with cancer before stroke was $25.9 \pm 32.4$ months, while the mean duration in patients diagnosed with cancer $(n=15)$ after stroke was $5.2 \pm 4.9$ months (0-12) (Table II).

A total of 17 different types of cancer were detected. Detected cancer types were as follows; 11 breast cancer, 7 colon cancer, 5 stomach cancer, 5 rectum cancer, 4 pancreas cancer, 4 prostate cancer, 4 lung cancer, 3 larynx, 3 renal cancer, 3 ovary cancer, 2 floor of mouth cancer, 1 liver tumor, 1 bone tumor, 1 skin, 1 urethra, 1 tongue cancer and 1 cancer of unknown primary. Cancer types according to the time of the cancer diagnosis are presented in detail in Figure.

Metastasis was detected in 8 of 42 patients who were diagnosed with cancer before having a stroke, while no metastasis was found in 25 patients. On the other hand, no clear information could be obtained regarding the metastasis of 9 patients. Metastasis was detected in 7 of 15 
Diagnosis of cancer in stroke patients

Table 1. Clinical and radiological features of stroke patients with and without cancer.

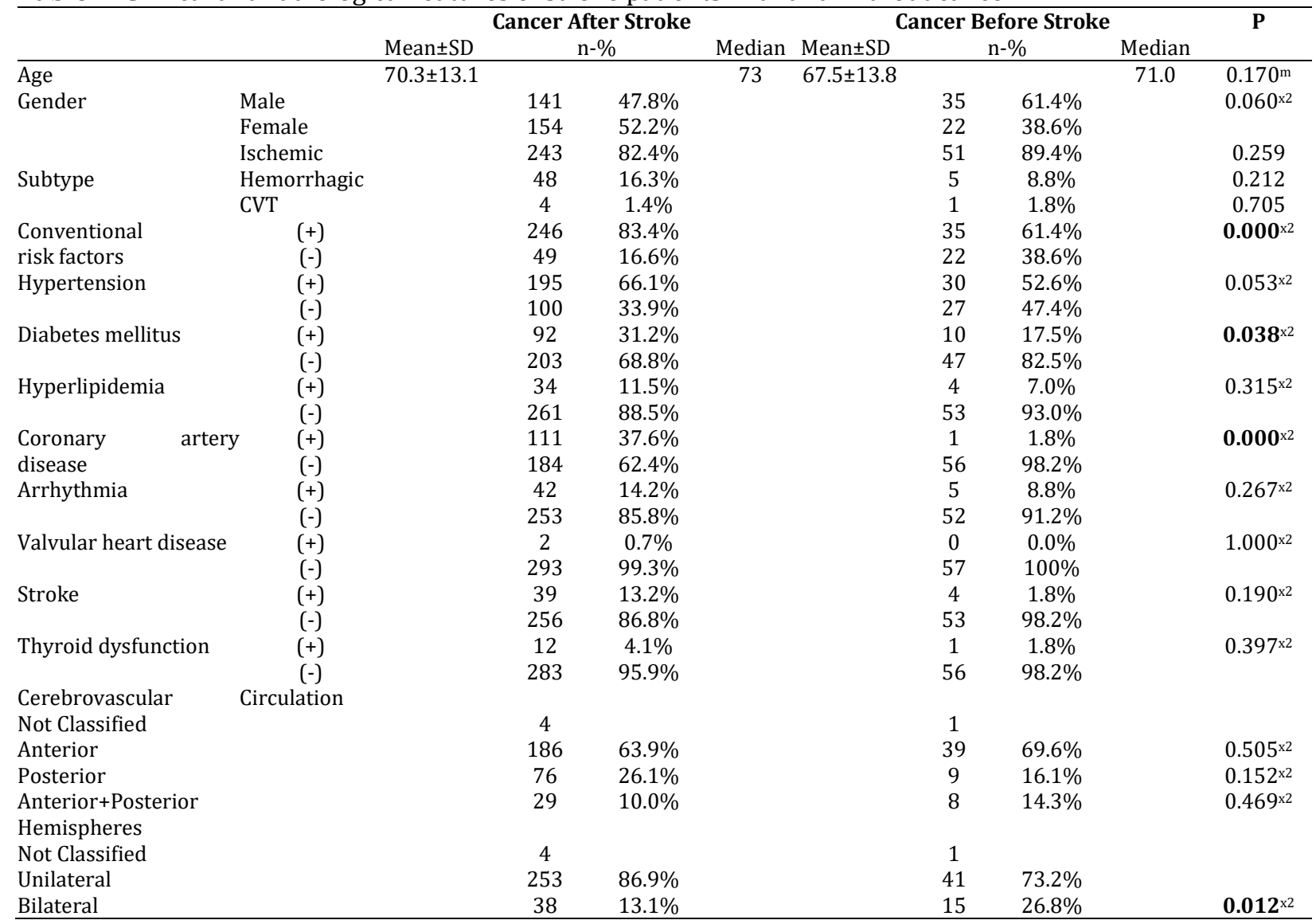

THE TIME OF THE CANCER DIAGNOSIS

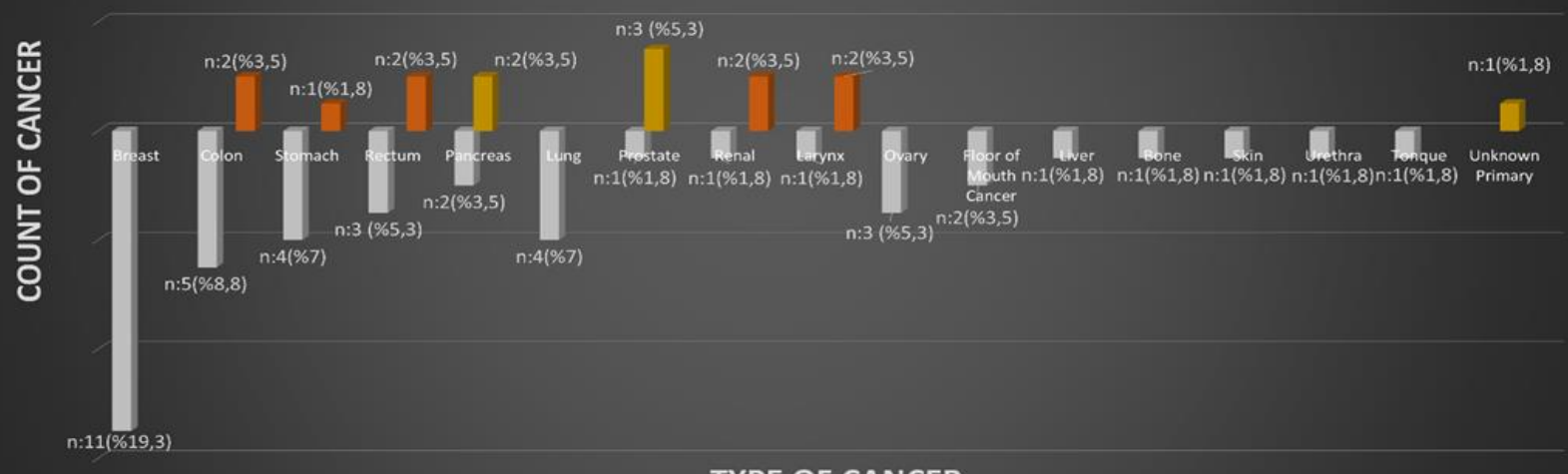

TYPE OF CANCER

- Before Stroke $\quad$ At the Same Time After Stroke

Figure. The time of cancer diagnosis and cancer types of stroke patients.

Turkish Journal of Cerebrovascular Diseases 2021; 27(2): 160-168 
Özözen Ayas et al.

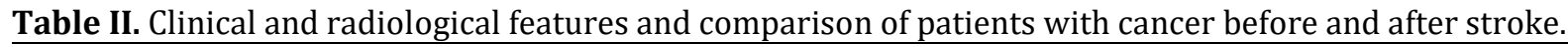

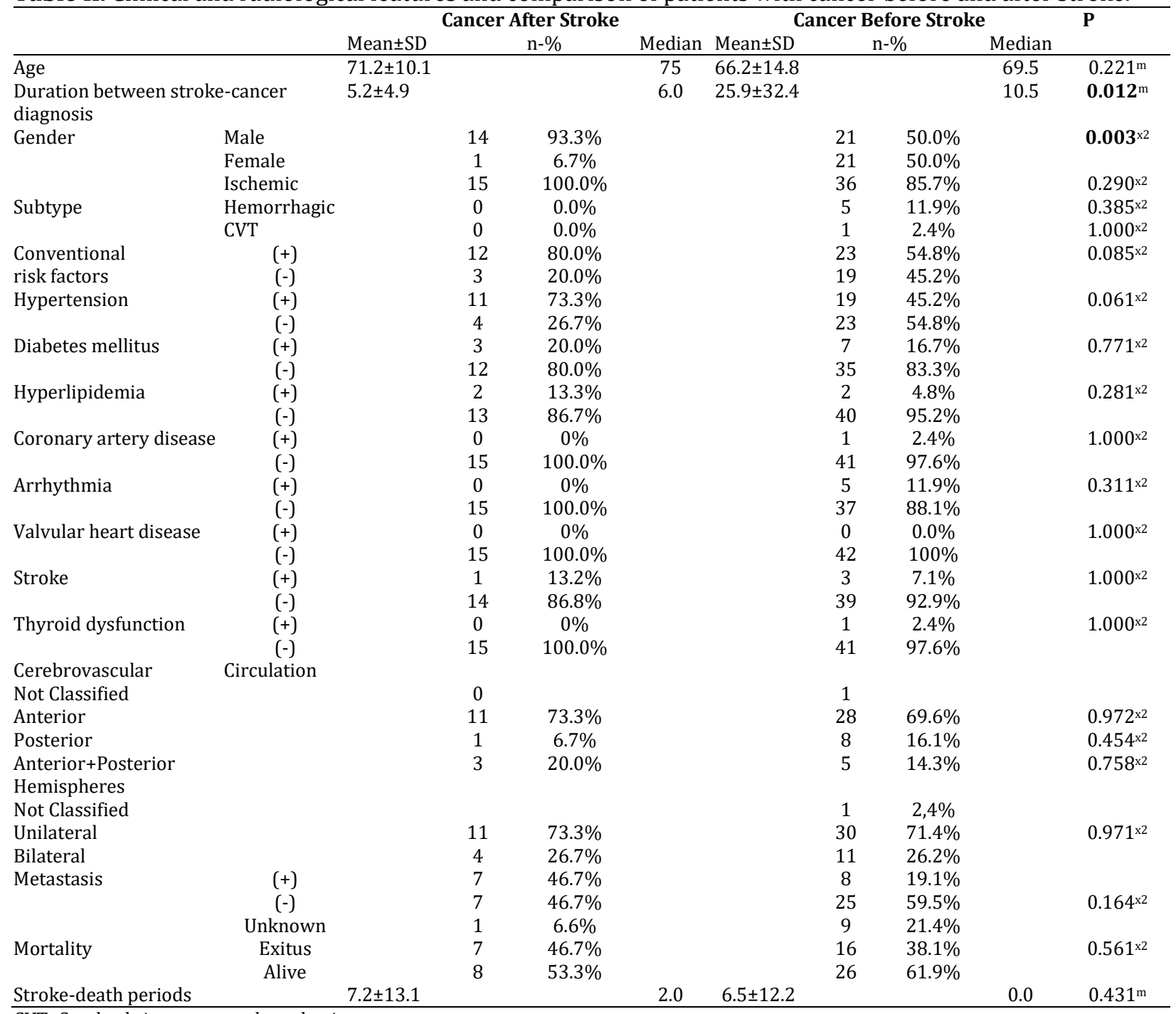

CVT: Cerebral sinus venous thrombosis.

patients who were diagnosed with cancer after stroke, whereas it was not detected in 7 patients and no clear information could be obtained related to one of the patients (Table II).

When the mortality of patients with cancer and stroke was assessed, it was determined that 23 patients $(40.4 \%)$ had been exitus. The duration of death after having a stroke was determined to be $6.7 \pm 12.3$ months $(0-50)$. When the death periods after having a stroke in patients who were diagnosed with cancer before and after having stroke were compared, no significant difference was determined.

When patients who were diagnosed with cancer before and after stroke were compared, no significant difference was found in terms of age, subtype of stroke, conventional risk factors, circulation and hemisphere involvement, presence of metastasis, and mortality (Table II).

\section{DISCUSSION AND CONCLUSION}

Cancer and stroke are diseases that have common risk factors such as advanced age, smoking, and obesity. The comorbidity of cancer and stroke is becoming increasingly prevalent because of the increasing number of elderly people in the society and due to the fact that cancer treatments increasing the risk of stroke and accelerating the conventional stroke mechanisms of cancer (13). In a study performed on stroke 
patients, it was revealed that having an age over 65 was significantly associated with the presence of active cancer (14). The mean age of patients with cancer and stroke in our study was $67.5 \pm 13.8$ years and no significant difference was determined between stroke patients with and without cancer in terms of age and sex. However, in our study, the rate of females was determined to be significantly higher in the group diagnosed with cancer before having a stroke compared to the group diagnosed with cancer after being diagnosed with stroke $(\mathrm{p}=0.003)$. In this group, there were breast cancer (11 patients), which was the most common type of cancer among females, and ovarian cancer ( 3 patients), which was the second most common gynecological malignancy. In a study, in which 25171 patients with breast cancer were examined, $7 \%$ of them were diagnosed with stroke during follow-up, and it was not clearly revealed whether this increased risk rose due to the breast cancer itself or due to the treatment (15). Although we did not have clear data regarding treatments provided to patients in our study, we considered that better survival of breast cancer compared to other cancers might increase the possibility of stroke.

In the event of the coexistence of cancer and stroke, the risk of developing stroke in the presence of cancer has been revealed at different rates in previous studies. It was found that stroke developed in $15 \%$ of cancer patients concurrently and $3.5 \%$ during the follow-up period (16-18). When stroke patients were examined, diagnosis of cancer was reported in $12 \%$ of 1274 stroke patients in a study (19). Active cancer was reported in $4.4 \%$ of patients presenting with acute ischemic stroke (14). In our study, a lower rate (1.8\%) of comorbidity of cancer and stroke was determined compared to the literature. We consider that this lower rate is due to the fact that follow-up of all 3098 stroke patients was not performed in our center.

In cancer patients, stroke can be seen in ischemic or hemorrhagic forms $(12,20)$. The incidence of ischemic infarctions in cancer and stroke is similar to that of hemorrhagic stroke $(4,10,21)$. Ischemic strokes are more common among patients with lymphoma and carcinoma, while hemorrhagic strokes are more common among patients with leukemia. Besides, cancers of the small intestine, liver, renal, nervous system, thyroid gland, endocrine glands, and connective tissue have been revealed as higher risk groups for hemorrhagic stroke (20). It has been observed that the risk of CVT is also increased in cancer patients, particularly in hematological tumors. Cancer is considered to be responsible for $8 \%$ of CVTs $(10,22)$. Contrary to the literature, it was found in a previous study that $93 \%$ of patients with comorbidity of cancer and stroke had ischemic stroke (6). Similarly, in our study, ischemic stroke was the most common with a rate of $89.4 \%$, whereas hemorrhagic stroke had an incidence of $8.8 \%$ and CVT had an incidence of $1.8 \%$. Stefan et al. reported the incidence of ischemic and hemorrhagic stroke among 153 cancer patients at $\% 86$ and $14 \%$, respectively. It was similar with non-cancer patients (19). Primary malignancies, hematological parameters, type of cancer treatments can effect subtypes of stroke. A clear clustering for any cancer entity with ischemic or hemorrhagic stroke subtypes could not be detected. However, the sample size concerning each tumour was small in our study.

Cancer and conventional stroke risk factors might coexist. Even, it has been considered that cancer accelerates the occurrence of these risk factors and directly causes stroke in a certain group (23). Conventional vascular risk factors of stroke patients with cancer have been revealed to be similar to those of stroke patients without cancer (19). The most common stroke risk factors in the case of cancer and stroke comorbidity are HT, HL, DM, AF, and smoking $(18,24)$. In a previous study, it was reported that HT and HL were less common in the stroke patients' group with cancer compared to the stroke group without cancer (25). A literature review reported that patients with cancer are subject to the same risk factors for stroke as the general population (26). Similarly, Stefan et al. reported that stroke risk factors do not significantly vary between cancer and noncancer patients (19). An other study reported that age and hypertension are important risk factors for stroke and trans ischemic attack in patients with breast cancer (27). In our study, the presence of conventional risk factors for stroke, DM, and CAD were found to be significantly higher in stroke patients without cancer compared to stroke patients with cancer. This suggests that the odds for cancer presence in the etiology is higher in stroke patients who do not have an underlying conventional risk factor. Also, our results thoughts that cancer induces stroke independent of 
conventional risk factors for stroke. Investigations of the pathophysiological mechanism of stroke induced by cancer must be performed with detailed analyses.

When the cerebrovascular system circulation was assessed, less posterior system involvement and multiple arterial regional involvement were reported among cancerous strokes in a previous study (25). Bilateral involvement and anteriorposterior system involvement are remarkable in strokes that occur as the first symptom of cancer (28). In our study, no difference was determined in terms of cerebrovascular circulation involvement. The bilateral hemisphere involvement rate was found to be significantly higher in the stroke with cancer than the stroke without cancer, in our study. $(\mathrm{p}=0.012)$

The duration between cancer and stroke diagnoses is varying in previous studies. In a previous study, the risk of ischemic and hemorrhagic stroke in the first 6 months following the diagnosis of cancer was revealed to be 1.6 and the SIR rate was 2.2 (20). Ischemic stroke rate was reported in $7 \%$ of patients with Hodgkin lymphoma during the 17.5-year follow-up period (29). It has been revealed that the risk of stroke peaked in 3 months among males and 6 months in females following the diagnosis of lung cancer, and the odds of stroke decreased within 1 year among males and 2 years among females after diagnosis (30). In our study, the mean duration between cancer and stroke diagnoses in stroke patients diagnosed with cancer was determined to be $25.9 \pm 32.4$ months. On the other hand, in our study, 6 patients were diagnosed with cancer concurrently with stroke, while 9 of them were diagnosed with cancer in the follow-up period after having a stroke, and the mean duration between stroke and cancer diagnosis was determined to be $5.2 \pm 4.9$ months. This duration suggests that the diagnosis of cancer might be missed in patients with acute stroke etiology and stroke may be the first symptom of cancer. Particularly, the fact that the duration is less than 1 year suggests that the cancer-stroke association is not coincidental. Hence, outpatient follow-up of patients after having a stroke should also be assessed from this point of view. Similarly, the first stroke was found to be at its highest level 0.5 years before and after cancer diagnosis (31).

The most common cancer diseases with stroke have been revealed to be urogenital, breast, and gastrointestinal malignancies (19). A higher incidence of stroke has been reported among patients who have been diagnosed with lung, pancreatic, colorectal, breast, and prostate cancers (32). In our study, the most common cancer types were breast, colon, stomach, and rectal cancers.

Zoller et al. revealed a higher risk of hemorrhagic and ischemic stroke in the presence of metastases (SIR 2, 1.5), (20). In our study, the presence of metastasis was detected in 15 patients (26.3\%). No significant difference was determined between having metastasis or not.

The mean survival was found to be shorter in patients with cancer-related stroke (25). In our study, the mortality of patients with cancer and stroke was $40.4 \%$, and the duration of death after having stroke was determined to be $6.7 . \pm 12.3$ months (0-50).

The limitations of the study are that the laboratory results and detailed neurovascular imaging results of the patients could not be assessed. Since all data could not be accessed due to the change made in the hospital database, the laboratory values of the patients were not examined. Since the treatments such as surgery, chemotherapy, or radiotherapy applied to the patients who were followed up in different centers, clear information could not be obtained and could not be clearly stated in our retrospective study. Detailed studies to be performed with the addition of these parameters would be able to reveal more clearly the correlation between stroke and cancer.

Guidelines are particularly needed for stroke prevention, identification, and management in cancer patients (7). A subgroup of stroke patients who would benefit greatest from the cancer patient group should be identified and a screening should be planned for them. Early diagnosis of cancer by screening facilitates the treatment decision for secondary stroke prevention through providing the detection of cancers that can be treated. Systematic studies are needed for the patients to be screened and the tests to be utilized. Treatment for the coexistence of cancer and stroke must be performed in an integrated manner by neurology and oncology specialists with a multidisciplinary approach (23).

Previous studies generally have analyzed patients who had a stroke with a cancer diagnosis. The evaluation of patients who were diagnosed with cancer concurrently with having a stroke or 
in the follow-up period after having a stroke is remarkable regarding the contribution of our study to the literature. It is considered that cancer might be encountered during or after the etiological investigation of the stroke patient, specifically in the first year, as well as the known cancer diagnosis in the history of stroke patients.

The absence of conventional risk factors for stroke and bilateral hemisphere involvement should make us think of the coexistence of cancer and stroke.

\section{REFERENCES}

1. Grisold W, Oberndorfer S, Struhal W. Stroke and cancer: A review. Acta Neurol Scand 2009; 119(1): 1-16.

2. Taccone FS, Jeangette SM. Blecic SA. First-ever stroke as initial presentation of systemic cancer. J Stroke Cerebrovasc Dis 2008; 17(4):169-174.

3. Dipasco PJ, Misra S, Koniaris LG, et al. Thrombophilic state in cancer, part I: Biology, incidence and risk factors. J Surg Oncol 2011; 104(3): 316-322.

4. Graus F, Rogers LR, Posner JB. Cerebrovascular complications in patients with cancer. Medicine (Baltimore) 1985; 64: 16-35.

5. Kneihsl M, Enzinger C, Wünsch G, et al. Poor short-term outcome in patients with ischaemic stroke and active cancer. J Neurol 2016; 263(1): 150-156.

6. Cerrahoğlu T Ș, Güler A, Şirin H, et al. Stroke and cancer association: Analysis of 30 patients. Ege Journal of Medicine 2013; 52(3): 155-159.

7. Zaorsky NG, Zhang Y, Tchelebi LT, et al. Stroke among cancer patients. Nat Commun. 2019; 10(1): 5172.

8. Rogers LR. Cerebrovascular complications in patients with cancer. Semin Neurol. 2010; 30(3): 311-319.

9. Dardiotis E, Alozou AM, Markoula S, et al. Cancerassociated stroke: Pathophysiology, detection and management (Review). Int J Oncol 2019; 54(3): 779-796.

10. Nazliel B. Cancer, paraneoplastic syndromes and stroke. Turkiye Klinikleri J Neurol-Special Topics 2014; 7(4): 125131.

11. Aarnio K, Joensuu H, Haapaniemi E, et al. Cancer in young adults with ischemic stroke. Stroke 2015; 46(6): 16011606.

12. Katz JM, Segal AZ. Incidence and etiology of cerebrovascular disease in patients with malignancy. Curr Atheroscler Rep 2005; 7(4): 280-288.

13. Bang YO, Chung JW, Lee MJ, et al. Cancer-Related Stroke: An emerging subtype of ischemic stroke with unique pathomechanisms. J Stroke 2020; 22(1): 1-10.

14. Grazioli S, Paciaroni M, Agnelli G, et al. Cancer-associated ischemic stroke: A retrospective multicentre cohort study. Thromb Res. 2018; 165: 33-37.

15. Nilsson G, Holmberg L, Garmo H, et al. Increased incidence of stroke with breast cancer. Eur J Cancer 2005; 41(3): 423429.

16. Newton HB: Neurologic complications of systemic cancer. Am Fam Physician 1999; 59(4): 878-886.

17. Arboix A: Cerebrovascular disease in the cancer patient. Rev Neurol 2000; 31(12): 1250-1252.
18. Chaturvedi DM, Ansell J, Recht L. Should cerebral ischemic events in cancer patients be considered a manifestation of hypercoagulability? Stroke 1994; 25(6): 1215-1218.

19. Stefan O, Vera N, Otto B, et al. Stroke in cancer patients: A risk factor analysis. J Neurooncol 2009; 94: 221-226.

20. Zöller B, Ji J, Sundquist J, et al. Risk of haemorrhagic and ischaemic stroke in patients with cancer: A nationwide follow-up study from Sweden. Eur J Cancer 2012; 48: 18751883.

21. Leira R, Davalos A, Castillo J. Cancer and paraneoplastic strokes. In: Caplan LR, Bogousslavsky J, ed. Uncommon causes of stroke. Cambridge Medicine 2008; 371-377.

22. Ferro JM, Canhão P, Stam J, et al. Prognosis of cerebral vein and subdural thrombosis: results of the International Study on Cerebral Vein and Dural Sinus Thrombosis (ISCVT). Stroke 2004; 35(3): 664-670.

23. Dearborn JL, Urritia VC, Zeiler SR. Stroke and Cancer- A complicated relationship. J Neurol Transl Neurosci. 2014; 2(1): 1039.

24. Zhang YY, Chan DKY, Cordato D, et al. Stroke risk factor, pattern and outcome in patients with cancer. Acta Neurol Scan 2006; 114(6): 378-383

25. Yeşilot N, Ekizoğlu E, Çoban O. Clinical features of cancer associated ischemic stroke. Arch Neuropsychiatry 2018; 55(2): 113-117.

26. Nguyen T, DeAngelis LM. Stroke in cancer patients. Curr Neurol Neurosci Rep 2006; 6:187-192.

27. Jags R, Griffith KA, Koelling T, et al. Stroke rates and risk factors in patients treated with radiation therapy for earlystage breast cancer. J Clin Oncol 2006; 24:2779-2785.

28. Kwon HM, Kang BS, Yoon BW. Stroke as the first manifestation of concealed cancer. J Neurol Sci. 2007; 258(1-2): 80-83.

29. De Bruin ML, Dorresteijn LD, van't Veer MB, et al. Increased risk of stroke and transient ischemic attack in 5-year survivors of Hodgkin lymphoma. J Natl Cancer Inst 2009; 101(13): 928-937.

30. Chen PC, Muo CH, Lee YT, et al. Lung cancer and incidence of stroke. Stroke 2011; 42(11): 3034-3039.

31. Wei YC, Chen HF, Wu CL, et al. Stroke rate increases around the time of cancer diagnosis. Front Neurol 2019; 10: 579.

32. Navi BB, Reiner AS, Kamel H, et al. Association between incident cancer and subsequent stroke. Ann Neurol 2015; 77(2): 291-300.

\section{Ethics}

Ethics Committee Approval: The study was approved by Eskişehir Osmangazi University Noninterventional Clinical Research Ethical Committee (Number: E-25403353-050.9977356, Date: 14. 07.2020).

Informed Consent: The authors declared that it was not considered necessary to get consent from the patients because the study was a retrospective data analysis.

Authorship Contributions: Surgical and Medical Practices: ZÖA, GU. Concept: ZÖA, GU. Design: ZÖA, GU. Data Collection or Processing: ZÖA, GU. Analysis or Interpretation: ZÖA, GU. Literature Search: ZÖA. Writing: ZÖA, GU.

Copyright Transfer Form: Copyright Transfer Form was signed by all authors.

Peer-review: Internally peer-reviewed.

Conflict of Interest: No conflict of interest was declared by the authors.

Financial Disclosure: The authors declared that this study received no financial support.

Copyright (c) 2021 by Turkish Cerebrovascular Diseases Society Turkish Journal of Cerebrovascular Diseases 2021; 27(2): 160-168 